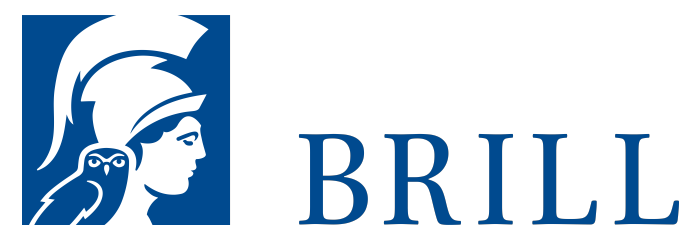

\title{
Religion Past and Present, Volume 14 Index
}

Authors: Hans Dieter Betz, Don Browning, Bernd Janowski, and Eberhard Jüngel

Religion Past and Present (RPP) is a complete, updated English translation of the 4th edition of the definitive encyclopedia of religion worldwide. the peerless Religion in Geschichte und Gegenwart (RGG). Including the latest developments in research, Religion Past and Present encompasses a vast range of subjects connected with religion. This great resource, now at last available in English, continues the tradition of deep knowledge and authority relied upon by generations of scholars in religious, theological, and biblical studies. Religion Past and Present indisputably belongs to the small class of essential reference works.

\section{Key Features}

- RGG has been a standard reference work since the publication of the first edition in 1908.

- Strongly international, cross-cultural and ecumenical, written by over 3,000 authors from 88 countries

- Covers an unparalleled breadth of subject matter in theological and biblical studies

- Up-to-date research and bibliographies make it an indispensable resource for all levels of users

- Interdisciplinary articles cover a wide range of topics from history, archaeology, liturgy, law, bible, music, visual arts, politics, social sciences, natural sciences, ethics, and philosophy.

- The 4th edition of RGG, the basis of the RPP translation, includes hundreds of new entries on Eastern religions and other religious subjects. The editors of...

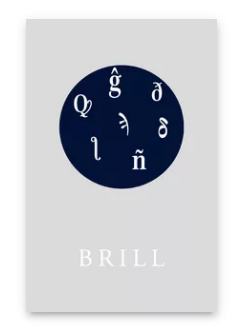

Language:

English

Subjects:

\section{General, Biblical}

Studies, General, History

Publisher: Brill

Series:

Religion Past and Present,

Volume: 14

E-Book (PDF)

Released online: 15 Sep 2013

ISBN: 978-90-

47-42652-3

Hardback

Publication date: o8 Oct 2013

ISBN: 978-9004-17305-7 List price USD \$350.00 
For more information see brill.com

Order information: Order online at brill.com +44330 333 0049 | customerservices@brill.com Submission information: brill.com/authors

Titles published by Brill | Fink, Brill | mentis or Brill | Schöningh: +49(o)715413279216| brill@brocom.de 